\title{
Właściwości negocjacji w Unii Europejskiej: wybrane aspekty teoretyczne
}

\section{Wprowadzenie}

Unia Europejska jako złożona struktura międzynarodowa o bezprecedensowym w historii stopniu zaawansowania integracji między swoimi członkami wykształciła szereg mechanizmów decyzyjnych, będących przedmiotem zainteresowania badaczy integracji europejskiej (zob. szerzej: Tallberg, 2010, s. 633). Niezaprzeczalnym faktem jest, że Unia Europejska w swojej złożoności dysponuje wieloma instrumentami, które umożliwiająjej funkcjonowanie na różnych płaszczyznach i różnych obszarach. Niemniej jednak, w literaturze przedmiotu panuje pogląd, że unijne procesy decyzyjne opierają się w sposób zasadniczy na negocjacjach (Jönsson, Elgström, 2005, s. 1). Każda z aktywności, którą podejmuje Unia Europejska wypracowywana jest poprzez negocjacje (Dür, Mateo, Thomas, 2010, s. 613). W następstwie tego, Unia Europejska jest określana jako „byt permanentnie negocjujący" (permanent negotiation institute) lub nawet „maraton negocjacyjny" (negotiation marathon) (Jönsson, Elgström, 2005, s. 1). Znaczenie negocjacji jako zasadniczego instrumentu podejmowania decyzji akcentują badacze procesów integracyjnych w UE, argumentując, że to w ich wyniku wypracowywane są decyzje, które zapewniają postęp integracji, a bez nich mogłoby dojść do dezintegracji. Taka zależność nie występuje w żadnym innym rodzaju negocjacji międzynarodowych (Meerts, 2004, s. 217-218).

W niniejszym artykule przedstawione zostały wybrane aspekty teoretyczne właściwości negocjacji w Unii Europejskiej. Dobór analizowanych właściwości nie wyczerpuje całej złożoności negocjacji, ale ukazuje te najbardziej znaczące, stanowiące o ich specyfice. W pierwszej kolejności ukazani zostali aktorzy, którzy determinują negocjacje w UE i których różnorodność stanowi wyzwanie dla rozważań teoretycznych. Następnie, jako immanentna właściwość negocjacji w UE zaakcentowany został przedmiot negocjacji, który charakteryzując się specyficznymi cechami, skutkuje wielopoziomowością i wieloaspektowością negocjacji w UE. Z tym wiąże się kolejna właściwość, czyli fakt, że negocjacje te stanowią proces złożony $z$ etapów, które angażują różnorodnych aktorów na różnych poziomach i w zależności od tych płaszczyzn wymagają odmiennych aktywności, również od tych samych aktorów. Artykuł kończą rozważania na temat procesów top-down i bottom-up jako determinant negocjacji w Unii Europejskiej.

\section{Aktorzy negocjacji w Unii Europejskiej}

Negocjacje w Unii Europejskiej charakteryzują się właściwościami, których specyfika pozwala na ich wyraźne odróżnienie od klasycznych negocjacji międzynarodo- 
wych czy negocjacji wewnątrz państwa, co nie oznacza, że w ramach negocjacji unijnych nie występują cechy dwóch powyższych typów. Łącząc w sobie mechanizmy negocjacji międzynarodowych i wewnątrzpaństwowych oraz wykształcając sobie specyficzne, negocjacje w Unii Europejskiej przyjmują postać „negocjacji hybrydowych” (hybrid EU negotiations) (Jönsson, Elgström, 2005, s. 1).

Owa hybrydowość manifestuje się, w pierwszej kolejności, w kwestii aktorów procesu negocjacyjnego. Negocjacje w UE angażują instytucje unijne oraz państwa członkowskie w różnych schematach powiązań, w zależności od tematu negocjacyjnego, a także etapu procesu negocjacyjnego (o którym będzie mowa w dalszej części). Ponadto, w wyniku wielotematycznej aktywności Unii Europejskiej, w negocjacje unijne angażują się również inni aktorzy, tacy jak rządy regionalne, organizacje pozarządowe, transnarodowe grupy interesu i zawodowi lobbyści, których wpływ jest zauważalny, zwłaszcza na strategicznym etapie budowy propozycji i stanowisk negocjacyjnych. Mowa tutaj w szczególności o transnarodowych grupach interesu i zawodowych lobbystach. Złożoność i wieloaspektowość integracji europejskiej wygenerowała również pojawienie się nowych aktorów w procesie negocjacji w Unii Europejskiej. W literaturze przedmiotu wskazuje się na rosnące znaczenie tzw. ekspertów PAM (Public Affairs Management), których pojawienie się w procesach negocjacyjnych jest konsekwencją ewolucji widocznej na arenie integracyjnej i przejawiającej się tym, że zawodowi dyplomaci są postawieni przed koniecznością delegowania części uprawnień negocjacyjnych na rzecz ekspertów. We współczesnym procesie negocjacyjnym udział dyplomatów i polityków jest najbardziej zauważalny podczas stadium procesu w Radzie Unii Europejskiej (van Schendelen, 2004, s. 29). Eksperci PAM wychodzą poza kategorię klasycznego lobbysty, bowiem ich działalność jest wyłączenie skierowana na uzyskanie wpływu na proces decyzyjny w Unii Europejskiej. Taki wpływ rośnie wraz z zadaniami, do których są powoływani, a mianowicie do pogłębionego badania natury i specyfiki procesów integracyjnych, identyfikowania szans i zagrożeń wynikających z rezultatów powyższych badań dla grupy, którą reprezentują, prześwietlania płaszczyzn negocjacyjnych i interesów poszczególnych graczy, opracowywania propozycji i dossiers negocjacyjnych, a także analizowania przyczyn sukcesów i porażek negocjacyjnych (van Schendelen, 2004, s. 31-32). Jednocześnie, to czym dodatkowo wyróżnia się ekspert PAM od klasycznego lobbysty, to fakt, że ten pierwszy odpowiada za wewnętrzną implementację rezultatów powyższych działań, jak również organizuje płaszczyzny współpracy z urzędnikami unijnymi, odpowiedzialnymi za określony segment tematyczny (van Schendelen, 2004, s. 32). Powyższe cechy skutkują przeniesieniem ciężaru negocjacyjnego $\mathrm{z}$ dyplomatów na ekspertów PAM, którzy określani są mianem archetypu negocjatora Unii Europejskiej, będącego odpowiedzią na specyficzną naturę UE i mogącego funkcjonować w ramach tej specyficznej natury (Meerts, 2004, s. 220).

$Z$ racji wielości aktorów, w tym nowych, negocjacje w Unii Europejskiej występują zatem na kilku płaszczyznach, m.in.: między państwami członkowskimi w Radzie Unii Europejskiej, między instytucjami unijnymi i państwami członkowskimi, między instytucjami unijnymi czy też w różnych innych konfiguracjach z udziałem pozostałych aktorów zainteresowanych i zaangażowanych w proces negocjacyjny.

Ta złożoność aktorów, generująca wielość płaszczyzn negocjacyjnych jest przedmiotem rozważań teoretycznych w studiach nad integracją europejską i skutkuje trud- 
nościami definicyjnymi (Cede, 2004, s. 8). Dwa czołowe podejścia, międzyrządowe i ponadnarodowe, inaczej definiują negocjacje w Unii Europejskiej właśnie ze względu na odmienne postrzeganie wagi i znaczenia poszczególnych aktorów dla procesu negocjacyjnego w UE.

W podejściu międzyrządowym głównymi graczami negocjacyjnymi są państwa członkowskie, które inicjują negocjacje i determinują ich przebieg poprzez rywalizację i grę swoich interesów, które definiowane są na poziomie narodowym. Efektem tych negocjacji ma być maksymalna satysfakcja interesów narodowych państw członkowskich (Moravcsik, 1993, s. 473). Aby tę satysfakcję uzyskać w ramach tak dużej liczby uczestników, państwa członkowskie wypracowują najniższy wspólny mianownik, który jest bazą dla dalszych negocjacji i który w założeniu obrony interesów narodowych wszystkich państw nie powinien być zmieniany. Biorąc pod uwagę te zależności, negocjacje unijne między państwami członkowskimi przypominają klasyczną dyplomację.

Drugie podejście, ponadnarodowe, sytuuje instytucje unijne, głównie Komisję Europejską na początku procesu negocjacyjnego i wskazuje je nie tylko jako inicjatorów, ale również „zarządzających” procesem, z racji wielokrotnie wspominanej złożoności natury UE (Cede, 2004, s. 11). Celem negocjacji jest budowa wspólnego interesu wszystkich graczy, co skutkuje tym, że rezultat negocjacji odzwierciedla wolę polityczna, interesy oraz uwarunkowania determinujące wszystkich aktorów. $Z$ racji faktu, że państwa członkowskie „oddały” szereg własnych kompetencji na rzecz integrującej się struktury, klasyczny system westfalski nie ma uzasadnienia w negocjacjach unijnych (Meerts, 2004, s. 219), a instytucje ponadnarodowe oraz inni gracze stają się niejednokrotnie głównymi aktorami determinującymi negocjacje (Cede, 2004, s. 10).

Charakteryzując negocjacje w Unii Europejskiej P. W. Meerts wskazuje, że stanowią one system pośredni między negocjacjami międzynarodowymi a negocjacjami narodowymi (Meerts, 2004, s. 218). Przejawia się to w tym, że nawet jeśli na płaszczyźnie międzyrządowej negocjacje przypominają klasyczne pertraktacje międzynarodowe, to można i tak zdiagnozować w nich pierwiastki ponadrządowości. Podstawową płaszczyzną negocjacji międzyrządowych są konferencje międzyrządowe (Intergovermental Conferences, IGC), które traktowane są jako jedno z głównych źródeł władzy i kontroli państw członkowskich nad procesem integracji europejskiej. Badania wskazuja jednak, że proces negocjacyjny podczas konferencji międzyrządowych nie ma wyłącznie charakteru międzyrządowego. Strategiczność tematów i związane z nimi wysokie koszty i zyski zobowiązań negocjacyjnych otwierają drogę dla Komisji Europejskiej, której ekspercki charakter przekłada się na jej znaczenie podczas negocjacji między państwami członkowskimi (Beach, 2004, s. 72). Rola Komisji przejawia się w układaniu agendy negocjacyjnej wraz z komplementarnie opracowanymi propozycjami negocjacyjnymi, przekonywaniu państw członkowskich do wypracowania rezultatów możliwie najbardziej „wspólnotowych i integracyjnych”, a nawet mediacji między negocjującymi członkami.

Podobną naturę zależności można odnaleźć w Komisji Europejskiej, w której badacze integracji europejskiej potwierdzają znaczenie pierwiastków narodowych. Jak wskazuje S. Suvarierol: „Pomimo tego, że Komisja Europejska powinna działać niezależnie od interesów narodowych, państwa członkowskie przywiązują ogromną wagę do posiadania swoich narodowych reprezentantów w Komisji na każdym jej poziomie. 
Państwa członkowskie nie tylko chcą, aby różnorodność w Europie była odzwierciedlana poprzez Komisję Europejską, ale także chcą zagwarantować, aby ich narodowa mentalność, refleksje oraz interesy były reprezentowane przez swoich urzędników w Komisji" (2011, s. 181-182). Badania nad wplywem pierwiastka narodowego w Komisji Europejskiej wskazują kolejne, daleko idące zależności, na przykład przy obsadzaniu kluczowych stanowisk. M. Egeberg (1996, s. 726) diagnozuje, że część dyrekcji zdominowana jest przez przedstawicieli określonych państw członkowskich, np. Niemców w dyrekcjach spaw zagranicznych.

Wzajemne przenikanie się tendencji i mechanizmów międzyrządowych i ponadnarodowych, a także duża liczba aktorów unijnego procesu negocjacyjnego powodują, że teoretyczne umiejscowienie negocjacji w UE znajduje najpełniejsze odzwierciedlenie w koncepcji wielopoziomowego zarządzania (multi-level governance). Jedni z głównych teoretyków tej koncepcji, L. Hooghe i G. Marks zakładają, że Unia Europejska stanowi system, na który składają się permanentne negocjacje między różnymi aktorami na wielu poziomach (2003, s. 234). Z koncepcją wielopoziomowego zarządzania współgrają również inne, których założeniem jest uwzględnienie maksymalnej ilości zmiennych tworzących całość systemu politycznego Unii Europejskiej oraz zaakcentowanie specyficznych tendencji w procesach integracyjnych. Wśród nich znajdują się m.in. koncepcja zarządzania policentrycznego (polycentric governance) autorstwa $\mathrm{Ph}$. C. Schmittera, która oznacza „wytwarzanie powiązań między wieloma aktorami, które delegują funkcjonalne zadania na wiele rozproszonych i stosunkowo niezależnych agencji" (za: Ruszkowski, 2013, s. 14). J. Torfing, B. G. Peters, J. Pierre oraz E. Sorensen opracowali koncepcję zarządzania interaktywnego (interactive governan$c e$ ), której założeniem jest, że w ramach funkcjonowania interaktywnych płaszczyzn rodzi się proces zarządzania „cechujący się dużym pluralizmem aktorów społecznych i politycznych, którzy wzajemnie na siebie oddziałują, nawet gdy mają rozbieżne interesy" (za: Ruszkowski, 2013, s. 14). Istotne specyficzne tendencje w integracji europejskiej podkreślają również: B. Kohler-Koch w swojej kategorii transformation of governance, która akcentuje transformację roli i kompetencji państwa na skutek procesów integracyjnych, które przesuwają „dystrybucję kompetencji między wieloma poziomami władzy" oraz G. Majone, który zwrócił uwagę na wspomnianą powyżej rosnącą rolę ekspertów w koncepcji expert governance (za: Ruszkowski, 2013, s. 14-15). Na uwagę również zasługują koncepcje, które podkreślają szeroki obszar tematyczny, który jest przedmiotem uwagi ze strony Unii Europejskiej. W ten nurt wpisują się koncepcje zarządzania regulacyjnego (regulatory governance) i zarządzania eksperymentalnego (experimentalist governance). W pierwszym przypadku akcentuje się, że Unia Europejska reguluje nieporównywalnie większą liczbę dziedzin w porównaniu do innych struktur międzynarodowych, czego apogeum jest rynek wewnętrzny, natomiast w drugim przypadku podkreśla się, że Unia Europejska wykazuje stałą tendencję do regulowania nowych kwestii, co wymaga działań innowacyjnych i eksperymentalnych (za: Ruszkowski, 2013, s. 14-15).

Wspólnym mianownikiem powyższych koncepcji jest założenie, że proces negocjacyjny w Unii Europejskiej nie jest skoncentrowany w jednym centrum decyzyjnym, ale jest rozproszony na wielu płaszczyznach, na których działają różni aktorzy. Jednocześnie, cechą specyficzną negocjacji unijnych jest to, że poszczególne sekwencje ne- 
gocjacji mogą mieć charakter ponadnarodowy, międzyrządowy, a także mieszany. Co również ważne, aktorzy procesu negocjacyjnego zmieniają się na różnych stadiach negocjacji, co oznacza, że zarówno przedmiot negocjacji, jak również ich przebieg nie jest monitorowany przez jednego negocjatora, ale całą grupę zróżnicowanych (nawet ukrytych) graczy na wielu płaszczyznach (Ch. Jönsson, S. Tägil, G. Törnqvist, 2000, s. 128-129; zob. też O. Elgström, M. Smith, 2000, s. 677).

\section{Specyfika przedmiotu negocjacji w Unii Europejskiej}

Kolejna właściwość, będąca immanentną cechą negocjacji unijnych, wiąże się $\mathrm{z}$ tendencją Unii Europejskiej do regulowania szerokiego spektrum przestrzeni publicznej i prywatnej, co determinuje przedmiot negocjacji, który w przypadku negocjacji unijnych nie ogranicza się zazwyczaj do jednego tematu. Negocjacje unijne rzadko zamykają się w ramach jasno zdefiniowanej perspektywy czasowej, a przedmiot negocjacji obejmuje więcej niż jeden temat (multi-issue negotiations), co w efekcie generuje nowe jakości, problemy lub sytuacje wymagające dalszych rozmów. W konsekwencji, określony temat negocjacyjny kreuje kolejny, nadając negocjacjom unijnym charakter permanentny (Jönsson, Tägil, Törnqvist, 2000, s. 128-129; Dür, Mateo, Thomas, 2010, s. 615).

Częściowo wynika to z faktu, że w agendzie negocjacyjnej zapisane jest kilka kwestii, będących przedmiotem rozmów w trakcie określonej sesji. Najczęściej jednak jest to rezultatem strategii negocjacyjnej wszystkich zainteresowanych aktorów zakładającej możliwości budowy transakcji wiązanych (Dür, Mateo, Thomas, 2010, s. 615).

W literaturze przedmiotu, H. E. McKibben stawia teze, że temat jest jedną z głównych determinant postaw i strategii negocjacyjnych aktorów procesu negocjacyjnego w UE. Określona specyfika przedmiotu negocjacji warunkuje charakter i rodzaj negocjacji w UE. W tym kontekście badaczka wyróżnia kilka kryteriów diagnozy (McKibben, 2010, s. 696-699):

a) w pierwszym kryterium determinantą warunkującą przebieg negocjacji jest określenie czy negocjacje toczą się $\mathrm{w}$ tematach z zakresu tzw. high czy low politics. Przedmioty negocjacyjne z zakresu high politics, dotyczące strategicznych interesów państw członkowskich, generują twarde negocjacje z postawami charakteryzowanymi maksymalistycznym dążeniem do satysfakcji tych interesów. Ten typ negocjacji określa się mianem negocjacji dystrybucyjnych (distributive bargaining). Tematy low politics, odnoszace się głównie do zagadnień wspólnotowych, uznawane są za takie, które sprzyjają, a nawet wymuszają konsensualny rodzaj negocjacji, oparty na wspólnym poszukiwaniu rozwiązania problemów negocjacyjnych. W tym kontekście mówi się o negocjacjach integrujących (integrative bargaining) (Odell, 2010, s. 621). W Unii Europejskiej, pierwszy typ jest najczęściej spotykany podczas konferencji międzyrządowych, jak również w tematach takich jak polityka zagraniczna i obronna. Drugi typ dominuje w obszarach związanych z politykami wspólnotowymi;

b) diagnoza w kolejnym kryterium wiąże się z zakwalifikowaniem przedmiotu negocjacji do grupy tematów o tzw. sumie zerowej (zero-sum issue) oraz tzw. sumie do- 
datniej (positive-sum issue). Pierwsza grupa skutkuje negocjacjami twardymi z racji faktu dużego stopnia różnicy interesów oraz strategicznego bilansu zysków i strat aktorów negocjacyjnych. Klasycznymi przykładami takich tematów są Wspólna Polityka Rolna czy Wspólna Polityka Rybołówstwa. W przypadku negocjacji w tematach o sumie dodatniej, aktorzy procesu negocjacyjnego są skłonni do przyjmowania kompromisowych postaw i zachowań negocjacyjnych;

c) trzecie kryterium diagnozy koncentruje się na określeniu stopnia newralgiczności tematu negocjacyjnego dla poszczególnego państwa członkowskiego (domestic issue salience). Tematy strategicznie wrażliwe (ze względu na układ polityczny, stabilność koalicji, preferencje większości parlamentarnej, oczekiwania opinii publicznej, czy wreszcie wskaźniki finansowe) dla określonego państwa członkowskiego warunkują jego twardą postawę w procesie negocjacyjnym, podczas gdy tematy mniej newralgiczne ułatwiaja negocjacje integrujące.

Jak wynika z powyższego, tematy negocjacyjne w Unii Europejskiej mogą i generują stan konfliktu w postaci nie tylko faktu istnienia rozbieżnych interesów, ale również różnego stopnia percepcji tych rozbieżności przez aktorów procesu negocjacyjnego, należy jednak zauważyć, że uczestnicy negocjacji przystępują do negocjacji jako partnerzy świadomi faktu, że ich relacje nie ograniczają się do chwili obecnej i trwać będą w przyszłości. Ta perspektywa relacji $\mathrm{w}$, cieniu przyszłości” (distant shadow of the future) jest immanentną cechą powiązań między aktorami unijnego procesu negocjacyjnego, powodując jego znaczące ułatwienie (Dür, Mateo, Thomas, 2010, s. 615). W wyniku praktyki negocjacyjnej w Unii Europejskiej wykształciła się metoda budowy transakcji wiązanych i łączenia kwestii (issue linkage) (McKibben, 2010, s. 700-701), która wynika z faktu, że państwa członkowskie inaczej ewaluują i „wyceniają” wartość koncesji i zysków w określonym temacie znajdującym się na stole negocjacyjnym. Manewry przy budowie transakcji wiązanych są zatem stałą częścią procesu negocjacyjnego UE, umożliwiającą uzgodnienie określonych kwestii i satysfakcję interesów wszystkich aktorów procesu, a tym samym warunkującą postęp integracji europejskiej.

\section{Etapy procesu negocjacyjnego w Unii Europejskiej}

Unia Europejska jako wielopoziomowy system generuje dla aktorów negocjacji szereg płaszczyzn aktywności, co skutkuje dla nich koniecznością mobilizacji negocjacyjnej praktycznie na każdym etapie unijnego procesu decyzyjnego. Co istotne, każda z tych płaszczyzn wymaga aktywności różnych aktorów i charakteryzuje się sobie właściwą specyfiką. H. Wallace wyróżnia 4 fazy procesu decyzyjnego UE, które stwarzają płaszczyzny negocjacyjne: faza projektowania (phase of policy design), faza negocjowania (phase of policy negotiation), faza legitymizowania (phase of policy legitimation) oraz faza implementacji (phase of policy implementation) (Wallace, 2005, s. 29).

W fazie projektowania w odniesieniu do tradycyjnych polityk wspólnotowych inicjatywa znajduje się w gestii Komisji Europejskiej, której potencjał w procesie decyzyjnym UE wynika z faktu, że ma ona kompetencje i jednocześnie dysponuje kwalifikacjami do opracowania projektów i stanowisk negocjacyjnych. Oznacza to, że Komisja Euro- 
pejska nadaje merytoryczny kształt i rysuje marginesy, w ramach których poruszają się pozostali aktorzy procesu decyzyjnego UE w następnych jego etapach. Jak wskazują badania, propozycje wysuwane przez Komisję Europejską są modyfikowane w dalszych etapach w stosunkowo małym procencie (około 20 procent zmian) (van Keulen, 2004, s. 37). Jednak z racji swojego ponadnarodowego charakteru, skutkującego chyba najwyższym stopniem zeuropeizowania swoich urzędników, Komisja Europejska nie tworzy propozycji negocjacyjnych w próżni, ale wykształciła szereg kanałów komunikacji (m.in. poprzez konsultacje) z potencjalnymi adresatami rezultatów tych propozycji (Wallace, 2005, s. 29), będącymi niejednokrotnie również innymi aktorami procesu negocjacyjnego. Kanały te są również dostępne dla państw członkowskich, które nie są formalnie zaangażowane $\mathrm{w}$ faze projektowania. W badaniach nad strategiami integracyjnymi państw członkowskich wyróżnia się rządy aktywne, które eksplorują te kanały, aby zabezpieczyć swoje preferencje narodowe w projekcie wspólnotowym już w fazie inicjatywy oraz rządy bierne, które wstrzymują się z działaniem do czasu ukonstytuowania się całej propozycji. Podział ten funkcjonuje zazwyczaj w kontekście potencjału i siły danego państwa, a także newralgiczności określonego obszaru negocjacyjnego (Wallace, 2005, s. 29-30). W swoich badaniach nad czynnikami warunkującymi sukces aktora procesu negocjacyjnego, S. Bailer potwierdza postawioną przez siebie tezę, że im bliżej stanowiska Komisji Europejskiej jest stanowisko negocjacyjne danego aktora, tym większe jego szanse na sukces w rokowaniach (Bailer, 2004, s. 104).

Druga faza jest tym etapem procesu negocjacyjnego, która wymaga największej inwestycji wysiłków i działań państw członkowskich w celu finalnego uformowania propozycji Komisji Europejskiej. Państwa członkowskie negocjują w ramach Rady Unii Europejskiej, której struktura zapewnia fora negocjacyjne dla różnych przedstawicieli państw członkowskich: od ministrów przez stałych przedstawicieli po ekspertów w grupach roboczych (Bal, 2004, s. 127). Rada stanowi bardziej aktywne forum interakcji między państwami członkowskimi, zapewnia najpełniejszą manifestację interesów narodowych państw członkowskich zwłaszcza, że posiedzenia Rady są często przedmiotem zainteresowania ze strony mediów, co dodatkowo wzmacnia pozycje narodowe (Wallace, 2005, s. 31).

Z racji wielokrotnie podkreślanej już złożoności integracji europejskiej, Rada Ministrów generuje dla państw członkowskich konieczność zróżnicowanej aktywności oraz elastycznych zachowań negocjacyjnych. Wynika to z faktu zróżnicowanego umiejscowienia pozycji i znaczenia Rady w różnych kontekstach integracyjnych. W literaturze przedmiotu akcentuje się, że w zależności od układów, w których funkcjonuje Rada, inaczej sytuują się wymagania, do których muszą ustosunkować się państwa członkowskie. H. Wallace wskazuje na różnice, które uwidaczniają się w układzie, kiedy Rada zawiązuje tandem z Komisją Europejską w obszarach objętych polityką wspólnotowa, kiedy Rada jest płaszczyzną permanentnej rywalizacji między państwami członkowskimi, kiedy Rada jest forum rozwijania nowych polityk, które nie były dotąd regulowane na poziomie unijnym, czy wreszcie kiedy Rada współdziała z Parlamentem Europejskim jako „europejska legislatura” (Wallace, 2005, s. 31). Mnogość ról pełnionych przez Radę implikuje różne rodzaje zachowań państw członkowskich, które znajdują się w środowisku jednoczesnej „symbiozy i napięcia” (Wallace, 2005, s. 31). 
Jednocześnie, należy pamiętać, że państwa członkowskie negocjują również w Radzie Europejskiej, strukturze powstałej w 1974 roku jako permanentne, nieformalne forum współpracy państw członkowskich. Usytuowanie Rady Europejskiej poza traktatami wspólnotowymi miało zagwarantować państwom członkowskim moc decyzyjną nieograniczoną przez instytucje wspólnotowe i tym samym umiejscowić negocjacje toczące się w ramach tej struktury bliżej klasycznych negocjacji międzynarodowych (Tallberg, 2010, s. 639-640).

W fazie legitymacji ujawnia się kolejna konsekwencja wielopłaszczyznowego charakteru negocjacji unijnych, a mianowicie wpływ negocjacji na wewnętrzną scenę polityczną państw członkowskich (Dorussen, Nanou, 2006, s. 235). W wyniku toczących się negocjacji w Unii Europejskiej w ruch wprawiane są krajowe partie polityczne, które stają przed obowiązkiem merytorycznego ustosunkowania się do procesu negocjacyjnego $\mathrm{z}$ racji strategicznego obowiązku państwa członkowskiego, jakim jest konieczność absorpcji zobowiązań negocjacyjnych w system wewnętrzny. W wielu państwach wykształcił się szereg mechanizmów partycypowania wewnętrznych sił politycznych w procesach negocjacyjnych, które prowadzone są w Brukseli. W ten sposób polityki unijne są legitymizowane przez państwo członkowskie, a nie wyłącznie przez ugrupowanie bądź koalicję rządzącą (Wallace, 2005, s. 33-34). W efekcie procesy decyzyjne na poziomie narodowym komplikują się, a niejednokrotnie polaryzują się w stopniu zdecydowanie większym w porównaniu do krajowych debat politycznych prowadzonych w odniesieniu do innych tematów międzynarodowych. Jak podkreślają S. Bulmer i Ch. Lequesne, integracja europejska implikuje nowe taktyczne i strategiczne opcje dla różnych typów aktorów politycznych w państwie członkowskim (Bulmer, Lequesne, 2005, s. 4).

W ostatniej fazie, implementacji, to przed państwami członkowskimi stoi największe wyzwanie zbudowania konturów struktur odpowiedzialnych za sprawne wdrożenie legislacji europejskiej, co w zależności od rodzaju systemu politycznego państwa członkowskiego może generować dalsze napięcia (Wallace, 2005, s. 35).

Podsumowując, proces negocjacyjny w Unii Europejskiej angażuje różnych aktorów, w tym państwo członkowskie w niezmiernie szerokim zakresie. Istotne jest, aby podkreślić, że specyfika integracji europejskiej również szeroko definiuje państwo członkowskie, które postrzegane jest nie tylko jako rząd narodowy, ale całokształt graczy wewnętrznych, a zatem również partie polityczne, parlamenty narodowe, samorządy, grupy interesu, opinię publiczną, a także sądy krajowe (Bulmer, Lequesne, 2005 , s. 2). Każdy z powyższych aktorów jest, naturalnie w różnych zakresie i wymiarze, elementem składowym machiny narodowej, która jako państwo członkowskie uczestniczy i współkreuje integrację europejską.

\section{Procesy top-down i bottom-up jako determinanty negocjacji w Unii Europejskiej}

W kontekście powyższego można zaryzykować tezę, że poprzez proces negocjacyjny w Unii Europejskiej najpełniej ujawnia się proces europeizacji, który jako pojęcie zostało niezmiernie szeroko opisane w literaturze przedmiotu, odnoszącej się do jego różnych aspektów i wymiarów (zob. m.in. Bulmer, Lequesne, 2005, s. 13). W odniesie- 
niu do negocjacji w UE należy przywołać ten segment definicyjny, który akcentuje wpływ integracji europejskiej na państwo członkowskie. R. Ladrech wskazuje, że europeizacja jest ,pogłębiającym się procesem reorientacji kierunku i ksztaltu polityki do takiego stopnia, że polityczna i ekonomiczna dynamika integracji europejskiej staje się częścią organizacyjnej logiki narodowej polityki i procesu decyzyjnego"; T. Börzel akcentuje, że jest to „proces w którym obszary polityki wewnętrznej stają się przedmiotem europejskiego procesu decyzyjnego"; C. Radaelli podkreśla natomiast, że europeizacja odnosi się do ,procesów konstrukcji, dyfuzji i instytucjonalizacji zasad formalnych i nieformalnych, procedur, paradygmatów polityki, stylów działania oraz wspólnie podzielanych norm i przekonań, które są najpierw definiowane i konsolidowane w unijnym procesie decyzyjnym, a następnie inkorporowane do logiki wewnętrznego dyskursu, tożsamości, struktur politycznych i polityk publicznych" (za: Bulmer, Lequesne, 2005, s. 12).

Proces europeizacji, określany ogólnie jako wieloaspektowy wpływ integracji europejskiej na państwa członkowskie nie oddaje w pełni zależności i mechanizmów, które występują w relacjach między państwem członkowskim a Unią Europejską. Aby zrozumieć skomplikowaną naturą procesów negocjacyjnych w UE, należy spojrzeć na państwo członkowskie nie tylko jako odbiorcę bodźców integracyjnych, ale również jako „dawce". W literaturze przedmiotu w obszarze dyskusji o europeizacji dokonuje się strategicznego rozróżnienia na procesy top-down oznaczające wpływ integracji europejskiej na państwa członkowskie oraz procesy bottom-up znamionujące wpływ państwa członkowskiego na integrację europejską (Börzel, 2005, s. 46). Siłą rzeczy, dla procesu negocjacyjnego w UE, procesy bottom-up stanowią kolejne, bardzo ważne uwarunkowanie determinujące w różny sposób każdy z etapów negocjacji w UE. Procesy bottom-up powoduja, że wiele z wewnętrznych mechanizmów politycznych promieniuje na unijny proces negocjacyjny, wpływając na jego przebieg i dynamikę. D. Finke wskazuje na kilka uwarunkowań, które dotycząc wewnętrznego procesu negocjacyjnego, wpływają na postawę państwa negocjującego w Brukseli (Finke, 2009, s. 487-491). Po pierwsze, akcentuje on wagę mechanizmów konsultacji, kooperacji i rywalizacji, które występują w rządzie narodowym, który buduje stanowisko negocjacyjne i tutaj zasadnicze uwarunkowanie dotyczy tego czy rząd jest jednopartyjny, czy koalicyjny (w tym przypadku ważną determinantą negocjacji wewnętrznych, a następnie unijnych jest to czy koalicja jest spójna czy skonfliktowana). Po drugie, istotnym uwarunkowaniem jest skład polityczny parlamentów narodowych, które w poszczególnych państwach członkowskich, w zależności od systemu politycznego, w różnym stopniu są angażowane w unijny proces negocjacyjny. Niemniej jednak, jeśli weźmiemy pod uwagę państwa, w których występuje formalna kontrola parlamentu nad rządem, rola tego pierwszego, choć niebezpośrednia w procesie negocjacyjnym, staje się zasadnicza. Po trzecie, nie można pominąć opinii publicznej, i to nie tylko w państwach członkowskich, które w swym katalogu instrumentów mają referendum. Opinia publiczna w państwie członkowskim, choć znowuż niebezpośrednio zaangażowana, jest ważnym cenzorem działań rządu narodowego, którego aktywność jest niejednokrotnie determinowana przez dynamikę kalendarza wyborczego. Jak potwierdza praktyka negocjacji unijnych, kalendarz, jak i agenda negocjacyjna podlega elastycznym korektom w zależności właśnie od kalendarza wyborczego w państwach członkow- 
skich, a tzw. strategiczne tematy pojawiają się na stole negocjacyjnym w określonej koniunkturze politycznej. Ponadto, cykle wyborcze skutkują tym, że proces decyzyjny na wewnętrznej scenie państwa członkowskiego niejednokrotnie zdominowany jest przez decyzje o charakterze krótkodystansowym, a partie rządzące zwykle unikają tematów, które mogą zagrozić ich pozycji w sondażach wyborczych (Franklin, Marsh, McLaren, 1994, s. 469). Co również warte podkreślenia, tematy negocjacji europejskich stają się przedmiotem debaty politycznej w państwie członkowskim, której celem jest satysfakcja partykularnych interesów partyjnych. W efekcie, negocjacje unijne mogą stać się zakładnikiem uwarunkowań wewnętrznych państwa członkowskiego $\mathrm{i}$ to $\mathrm{w}$ kontekstach politycznych, których negocjacje formalnie nie dotyczą (zob. szerzej: Curyło, 2012, s. 67-70).

Procesy top-down i bottom-up nie przebiegają oddzielnie, ale wzajemnie się warunkują i przenikają. W efekcie tego, jeden z kluczowych aktorów negocjacji unijnych, jakim jest rząd państwa członkowskiego, doświadcza tzw. paradoksu słabości, tj. mechanizmu, w którym krzyżują się ograniczenia i korzyści płynące z członkostwa w Unii Europejskiej. $Z$ jednej strony, państwo członkowskie jest ograniczane przez konieczność dzielenia się władzą (power-sharing) z innymi państwami członkowskimi i instytucjami unijnymi, ale $\mathrm{z}$ drugiej strony zagnieżdżenie spraw wewnętrznych w strukturze integracyjnej daje rządowi narodowemu możliwość odwołania się do tych ograniczeń w celu uzasadnienia własnych działań przed krajową opinią publiczną (Kassim, 2005, s. 288). W praktyce politycznej paradoks słabości oznacza możliwość uchylenia się od odpowiedzialności przed wyborcami za określone decyzje poprzez wykazanie własnej niemocy decyzyjnej. Faktycznie, wielokrotnie taka retoryka jest słuszna i odzwierciedla rzeczywiste kompetencje rządów narodowych w poszczególnych dziedzinach, objętych i regulowanych politykami wspólnotowymi, ale często argumentacja taka służy wyłącznie instrumentalnym celom politycznym liderów, którzy zyskują możliwość manewru retorycznego wobec nieświadomej opinii publicznej (Curyło, 2012, s. 67-70).

\section{Podsumowanie}

Znaczenie negocjacji jako instrumentu podejmowania decyzji w Unii Europejskiej zostało dostrzeżone i potwierdzone $\mathrm{w}$ badaniach nad integracją europejską. W rezultacie, Unia Europejska jest określana mianem negotiated order (Jönsson, Tägil, Törnqvist, 2000, s. 127), co można interpretować w dwojaki sposób. Po pierwsze, jako ład negocjacyjny - w tej interpretacji Unia Europejska stanowi system permanentnie negocjujący. Po drugie, jako ład wynegocjowany, co oznacza, że decyzje kontynuujące, stymulujące i projektujące progres procesu integracji zostały wynegocjowane (Elgström, Smith, 2000, s. 673).

W niniejszym artykule przedstawione zostały wybrane aspekty teoretyczne właściwości negocjacji w Unii Europejskiej. Dobór tych właściwości, choć z racji złożoności i wieloaspektowości negocjacji nie wyczerpuje całego spektrum kompleksowości tematu, dokonany został w oparciu o te najbardziej strategiczne. W pierwszej kolejności, należy wskazać mnogość aktorów w negocjacjach w Unii Europejskiej, którą rozważa się w kilku wymiarach: pod kątem występowania tradycyjnych i nowych uczestników 
negocjacji, problemów definicyjnych z tym związanych, a także płynącą z ich aktywności wielopoziomowością negocjacji w UE. Szczególnie ważnymi aktorami są państwa członkowskie, które traktowane są nie tylko jako rząd narodowy, ale konglomerat wewnętrznych graczy, którym integracja europejska otwiera możliwości i kanały dostępu do unijnych procesów negocjacyjnych, zmieniając tym samym układ sił na arenie narodowej.

Immanentną właściwością negocjacji w UE jest przedmiot negocjacyjny, który niezmiernie rzadko ogranicza się do pojedynczej kwestii, a stanowi raczej agregat zagadnień, skutkując tym, że negocjacje w UE w danym temacie generują konieczność następnych negocjacji, powodując, że proces negocjacyjny nabiera charakteru permanentnego, a jego rezultaty to zazwyczaj transakcje wiązane.

Kolejne ważne właściwości wiążą się z etapami procesu negocjacyjnego: projektowania, negocjowania, legitymizowania oraz implementacji. W każdym z tych etapów zachodzą inne zależności oraz wymagana jest różna aktywność uczestników procesu negocjacyjnego, nawet jeśli mówimy o tym samym typie aktora. Oznacza to, że na przykład państwo członkowskie jako negocjator staje przed koniecznością odgrywania odmiennych ról, przyjmowania zróżnicowanych pozycji negocjacyjnych oraz angażowania różnych wewnętrznych graczy na każdym $\mathrm{z}$ etapów.

Jako niezmiernie ważne właściwości uznane zostały procesy top-down i bottom-up, które ogólnie definiuje się jako wpływ integracji europejskiej na państwo członkowskie oraz wpływ państwa członkowskiego na UE. Analiza tych procesów pozwala zdiagnozować uwarunkowania, które wpływają na proces negocjacyjny w sposób zasadniczy, choć nie zawsze bezpośredni.

\section{Bibliografia}

Bailer S. (2004), Bargaining Success in the European Union: The Impact of Exogenous and Endogenous Power Resources, „European Union Politics”, nr 5(99).

Bal L. J. (2004), Member States Operating in the EU Council of Ministers: Inside Impressions, w: Negotiating European Union, red. P. W. Meerts, F. Cede, New York.

Beach D. (2004), EU Institutions and IGC Negotiations - How the EU Negotiation Process Affects Institutions' Ability to Gain Influence in IGCs, w: Negotiating European Union, red. P. W. Meerts, F. Cede, New York.

Börzel T. (2005), Europeanization: How the European Union Interacts with its Member States, w: The Member States of the European Union, red. S. Bulmer, Ch. Lequesne, Oxford University Press, Oxford.

Bulmer S., Lequesne Ch. (2005), The European Union and its Member States: An Overview, w: The Member States of the European Union, red. S. Bulmer, Ch. Lequesne, Oxford University Press, Oxford.

Cede F. (2004), Introduction, w: Negotiating European Union, red. P. W. Meerts, F. Cede, New York.

Curyło B. (2012), Negocjacje w procesie rozszerzenia Unii Europejskiej na Wschód: uwarunkowania, aktorzy, przebieg, Toruń.

Dorussen H., Nanou K. (2006), European integration, intergovernmental bargaining and convergence of party programmes, „European Union Politics”, nr 7. 
Dür A., Mateo G., Thomas D. C. (2010), Negotiation theory and the EU: the state of the art, „Journal of European Public Policy", nr 5(17), August.

Egeberg M. (1996), Organization and nationality in the European Commission services, „Public Administration", t. 74.

Elgström O., Smith M. (2000), Negotiation and policy-making in the European Union-processes, system and order, „Journal of European Public Policy”, nr 7(5)

Finke D. (2009), Domestic Politics and European Treaty Reform: Understanding the Dynamics of Governmental Position-Taking, „European Union Politics”, nr 10.

Franklin M., Marsh M., McLaren L. (1994), Uncorking the bottle: popular opposition to European unification in the wake of Maastricht, „Journal of Common Market Studies”, t. 32, nr 4.

Hooghe L., Marks G. (2003), Unraveling the central state, but how? Types of multi-level governance. „American Political Science Review”, t. 97, nr 2.

Jönsson Ch., Elgström O. (2005) Introduction, w: European Union Negotiations. Processes, networks and institutions, red. Ch. Jönsson, $\mathrm{O}$. Elgström, London-New York.

Jönsson Ch., Tägil S., Törnqvist G. (2000), Organzing European Space, Sage Publications, California.

Kassim H. (2005), The Europeanization of Member State Institutions, w: The Member States of the European Union, red. S. Bulmer, Ch. Lequesne, Oxford University Press, Oxford.

McKibben H. E. (2010), Issue characteristics, issue linkage, and states' choice of bargaining strategies in the European Union, „Journal of European Public Policy”, nr 17 (5), August.

Meerts P. W. (2004), Negotiating European Union, w: Negotiating European Union, red. P. W. Meerts. F. Cede, New York.

Moravcsik A. (1993), Power and preferences in the European Community: a liberal intergovernmentalist approach, „Journal of Common Market Studies”, t. 31, nr 4.

Odell J. S. (2010), Three islands of knowledge about negotiation in international organizations, „Journal of European Public Policy", nr 17 (5), August.

Ruszkowski J. (2013), Governance i jego typy w systemie wielopoziomowym. Zamiast wstepu, w: Multi-level governance w Unii Europejskiej, red. J. Ruszkowski, E. Wojnicz, Szczecin-Warszawa.

Suvarierol S. (2011), Everyday cosmopolitanism in the European Commission, „Journal of European Public Policy", nr 18 (2), March.

Tallberg J. (2010), Explaining the institutional foundations of European Union negotiations, „Journal of European Public Policy", nr 17(5), August.

van Keulen M. (2004), What Happens at Home-Negotiating EU Policy at the Domestic Level, w: Negotiating European Union, red. P. W. Meerts, F. Cede, New York.

van Schendelen R. (2004), The EU as a Negotiations Arena: Diplomats, Experts, and PAM Professionals, w: Negotiating European Union, red. P. W. Meerts, F. Cede, New York.

Wallace H. (2005), Exercising Power and Influence in the European Union: The Roles of Member States, w: The Member States of the European Union, red. S. Bulmer, Ch. Lequesne, Oxford University Press, Oxford.

\section{Streszczenie}

Artykuł koncentruje się na wybranych, najbardziej znaczących, aspektach teoretycznych właściwości negocjacji w Unii Europejskiej. Wśród nich znajdują się właściwości dotyczące: dużej liczby i różnorodności aktorów negocjacji; specyficznego przedmiotu negocjacji skutku- 
jącego wielopoziomowością i wieloaspektowością negocjacji w UE; wieloetapowością procesu negocjacji w UE, który angażuje różnorodnych aktorów na różnych poziomach i w zależności od tych płaszczyzn wymaga odmiennych aktywności negocjacyjnych i wreszcie procesów top-down i bottom-up jako determinant negocjacji w Unii Europejskiej.

Slowa kluczowe: europeizacja, negocjacje, procesy top-down, procesy bottom-up, Unia Europejska

\section{Properties of negotiations in the European Union: selected theoretical aspects}

\section{Summary}

The focus of the paper is the selected, most significant theoretical aspects of negotiations conducted within the European Union. They include the following: the large number and diversity of negotiators; the specific subject of EU negotiations, making them multi-level and multi-dimensional; the multistage character of EU negotiations and, thus, the involvement of various actors at different levels, calling for different kinds of negotiating activities; and, last but not least, the top-down and bottom-up processes that are the determiners of negotiations in the EU.

Key words: Europeanisation, negotiations, top-down processes, bottom-up processes, European Union 
